\title{
Sosialisi Menjadi Generasi Pemimpin Milenial Pada Masyarakat Cipinang Melayu Kecamatan Makasar Jakarta Timur
}

\author{
Kartika Yuliantari ${ }^{1}$ \\ Fakultas Ekonomi dan Bisnis, Universitas BSI, kartika.kkj@bsi.ac.id \\ Kus Daru Widayati ${ }^{2}$ \\ Fakultas Ekonomi dan Bisnis, Universitas BSI, kus.kdr@bsi.ac.id
}

\begin{abstract}
Abstrak
Kepemimpinan milenial berarti kepemimpinan yang dapat mengikuti dengan gaya yang dimiliki generasi masa kini. Pola kepemimpinan milenial berbeda dengan pola kepemimpinan dulu yang berasal dari generasi sebelumnya. Tujuan pengabdian masyarakat ini adalah mengubah pola mindset peserta agar menjadi generasi pemimpin milenial dan menambah ilmu dan pengetahuan di bidang kepemimpinan. Pengabdian masyaralat ini juga menumbuhkan kesadaran sebagai generasi penerus bangsa yang dapat mengetahui setiap kelebihan maupun kekurangannya agar menjadi seorang pemimpin milenial yang lebih bijaksana dan dewasa. Sedangkan untuk ibu-ibu PKK menyadari perannya sebagai orang tua dalam mendidik anaknya sedini mungkin, dalam membentuk moral dan pola pikir yang baik untuk menciptakan generasi pemimpin milenial yang mempunyai karakter sesuai dengan Pancasila. Sedangkan kegiatan pengabdian masyarakat ini berguna bagi pihak penyelenggara yaitu dosen Program Studi Administrasi Bisnis, Fakultas Ekonomi dan Bisnis beserta lembaga yang menaunginya adalah memenuhi salah satu kewajiban seperti tertuang dalam Tri Dharma Perguruan Tinggi yaitu Pengabdian Masyarakat yaitu ikut berperan secara aktif membuka wawasan dan pengetahuan seluruh masyarakat, khususnya generasi muda serta dapat melibatkan perempuan, khususnya seorang ibu yang dapat melahirkan generasi pemimpin milenial. Berdasarkan evaluasi terungkap, bahwa para peserta belum memahami karakteristik generasi milenial. Peserta juga belum memiliki mindset tentang generasi pemimpin milenial dan, begitu juga orang tua belum mengerti bagaimana mendidik anakanaknya agar menjadi generasi pemimpin milenial di masa yang akan datang. Namun, setelah mengikuti pelatihan, para peserta generasi muda akhirnya dapat memahami karateristik menjadi seorang pemimpin milenial, ibu-ibu PKK mulai menyadari bagaimana mendidik anak-anaknya sedini mungkin, dalam membentuk moral dan pola pikir yang baik agar menjadi seorang pemimpin milenial di masa yang akan datang yang mempunyai karakter sesuai dengan Pancasila dilihat dari tanggapan peserta setelah pelatihan.
\end{abstract}

Kata Kunci: Generasi, Pemimpin, Milenial

\begin{abstract}
Millennial leadership means leadership that can follow the style of today's generation. Millennial leadership patterns are different from past leadership patterns from previous generations. The purpose of community service is to change the mindset patterns of participants to become a generation of millennial leaders and increase knowledge and
\end{abstract}


knowledge in the field of leadership. This community service also fosters awareness as the next generation of the nation who can know each of its advantages and disadvantages in order to become a wiser and more mature millennial leader. Whereas for PKK mothers realize their role as parents in educating their children as early as possible, in forming good morals and mindset to create a generation of millennial leaders who have character in accordance with Pancasila. While this community service activity is useful for the organizers namely Business Administration Study Program lecturers, the Faculty of Economics and Business and its supporting institutions is fulfilling one of the obligations such as stated in the Tri Dharma of Higher Education namely Community Service which is actively participating in opening insight and knowledge throughout the community, especially the younger generation and can involve women, especially a mother who can give birth to a generation of millennial leaders. Based on the evaluation, it was revealed that the participants did not yet understand the characteristics of millennial generation. Participants also do not yet have a mindset about the generation of millennial leaders and, likewise parents do not yet understand how to educate their children to become generations of millennial leaders in the future. However, after attending the training, the young generation participants were finally able to understand the characteristics of being a millennial leader, PKK mothers began to realize how to educate their children as early as possible, in shaping good morals and mindset in order to become a millennial leader in the future. come who have the character in accordance with Pancasila seen from the responses of participants after the trainin.

Keywords : Generation, Leader, Millennial

\section{Pendahuluan}

\section{Latar Belakang}

Di masa ini, dalam setiap kehidupan yang harus dihadapi semakin banyak tantangan baik dalam kehidupan sehari-hari, dalam dunia kerja, maupun dalam dunia pendidikan. Kehadiran pemimpin di suatu organisasi atau kelompok individu dibutuhkan agar membawa suatu organisasi atau kelompok individu pada tujuan yang diharapkan. Beberapa macam gaya kepemimpinan akan mempengaruhi tingkah laku pemimpin ketika melaksanakan pekerjaannya. Karakteristik yang dimiliki oleh generasi milenial, akan membawa perilaku anak muda untuk lebih berhati-hati memilih pekerjaan yang diinginkan. Tahun 2020 sampai dengan 2030 diprediksi Indonesia akan mencapai puncak jumlah usia produktif yaitu sebesar 70 persen dari total penduduk Indonesia (Sebastian, 2016). Indonesia menurut data Biro Pusat Statistik tahun 2018 jumlah penduduk usia muda sangat besar yaitu sekitar 90 juta milenial yaitu yang berusia 20 sampai dengan 34 tahun, jumlah ini lebih banyak dibandingkan dengan lima negara Asia lainnya seperti Korea, India, Tiongkok dan Jepang. Penduduk usia produktif dapat berpotensi menggerakkan ekonomi Indonesia menjadi semakin tinggi. Hal ini bila dikelola dengan baik dengan menciptakan karakter generasi pemimpin milenial yang cocok untuk memimpin generasi milenial, maka dapat berpotensi menciptakan manfaat bagi peningkatan perekonomian dan menjadikan Indonesia yang maju. (Bosscher, 2013). 
Suatu organisasi dapat menjadi sukses dalam mencapai tujuannya apabila mempunyai seorang pemimpin yang dapat mengarahkan anggota aka tidak ada organisasi akan dapat mencapai kinerja yang paling diharapkannya. (Rohaeni, 2016). Bila jumlah penduduk usia muda yang sangat besar disiapkan dan dikawal dengan baik, maka dapat melahirkan pemimpin millennial Indonesia yang mandiri dan mempunyai kualitas tinggi. Generasi pemimipin milenial yang berkualitas, harus diberikan kesempatan dalam ruang organisasi formal untuk mengambil peran penting sebagai 'policy maker'. Generasi pemimpin milenial yang berkualitas adalah generasi yang mempunyai pola perilaku dominan berbasis teknologi canggih, digital baik secara online maupun offline dengan disertai kreatifitas yang tinggi.

Sebaliknya, jika jumlah penduduk usia muda yang sangat besar tidak dapat digunakan dengan maksimal, maka dapat menimbulkan bencana dan petaka. Banyaknya sumber daya manusia manusia produktif tetapi tidak berkualitas akan mengakibatkan timbulnya banyak masalah, mulai dari pengangguran, kemiskinan hingga terjadinya tingkat kriminalitas yang tinggi.

Berdasarkan latar belakang tersebut penulis mengadakan kegiatan Pengabdian kepada Masyarakat untuk memberikan pelatihan kepada Karang taruna Warga di RW 013 Cipinang Melayu Jakarta Timur yang anggotanya merupakan generasi muda yang perlu dibentuk untuk menjadi generasi pemimpin-pemimpin milenial sehingga dapat membantu mereka untuk mengetahui setiap kelebihan maupun kekurangan yang dimiliki dalam dirinya, sehingga diharapkan agar dapat terbentuk menjadi seorang pemimpin yang lebih bijaksana dan dewasa. Dengan demikian, diharapkan ke depannya akan menjadi calon pemimpin bangsa yang diharapkan mampu menjadikan Indonesia menjadi bangsa yang maju. Masa depan bangsa kita ada di tangan mereka, apakah bangsa ini akan semakin maju atau malah sebaliknya, semua itu ditentukan oleh pemuda generasi bangsa. Karang taruna merupakan suatu organisasi sosial sebagai sarana dalam pengembangan generasi muda yang tumbuh berkembang atas dasar kesadaran dan tanggung jawab sosial dari, oleh dan untuk masyarakat terutama generasi muda di suatu wilayah desa atau kelurahan, terutama bergerak di bidang usaha kesejahteraan sosial. Sementara itu, peran orang tua sangat besar untuk mendidik anaknya sedini mungkin dalam membentuk moral dan pola pikir yang baik untuk menciptakan generasi pemimpin milenial yang mempunyai karakter sesuai dengan Pancasila. Oleh karena itu, pelatihan ini juga mengikutsertakan ibu-ibu PKK Warga di RW 013 Cipinang Melayu Jakarta Timur. Dengan demikian, kita menginginkan agar generasi muda bangsa milenial menjadi generasi yang dapat mewujudkan bangsa Indonesia yang maju.

\section{Kajian Pustaka}

(Hasibuan, 2016) berpendapat bahwa pemimpin merupakan adalah seseorang yang menggunakan wewenang yang dimiliki untuk mengarahkan orang lain dan mempertanggungjawabkan semua pekerjaannya agar dapat mencapai satu tujuan. 
Dengan demikian, maka dibutuhkan seseorang sebagai seorang pemimpin yang mampu memberikan pengarahan kepada anggotanya untuk mencapai satu tujuan yang sudah ditetapkan sebelumnya.

Selain itu, (Hasibuan, 2016) menambahkan bahwa setiap orang yang menjadi pemimpin harus mempunyai sifat, watak, dan karakter yang dipengaruhi selain sifat-sifat yang telah dibawa sejak lahir juga dipengaruhi oleh pembentukan lingkungan tempat pemimpin itu bekerja.

Ada beberapa karakter generasi milenial ini menurut (Peramesti \& Kusmana, 2018) adalah, yang pertama seorang pemimpin harus mempunyai kemampuan dapat mengakses teknologi informasi, menguasai media sosial dan dunia internet yang menjadi sumber informasi. Selain itu generasi milenial mempunyai karakter berani dalam berinovasi. Generasi milenial juga berkarakter lebih suka terhadap mandiri dengan gaya hidup yang lebih bebas dalam melakukan sesuatu. Generasi milenial juga berkarakter lebih menyukai sesuatu yang instan. Dari sudut pandang positif, kesukaan akan sesuatu yang instan karena generasi ini lebih menyukai sesuatu yang bersifat praktis dan simpel, sedangkan segi negatifnya adalah generasi ini memipunyai daya juang yang lebih rendah apabila menghadapi tekanan dan stres karena sudah biasa melakukan sesuatu secara cepat dan instan.

Menurut (Peramesti \& Kusmana, 2018), yang dapat diperhatikan dalam gaya kepemimpinan milenial antara lain, yang pertama adalah Digital Mindset, yaitu kepemimpinan milenial perlu memahami dan menggunakan pola perilaku yang dominan berbasis teknologi canggih, secara online, digital disertai kreatifitas yang tinggi. Ruang pertemuan secara fisik berganti menjadi ruang pertemuan secara digital. Pemimpin milenial dapat memanfaatkan kemajuan teknologi untuk menjalankan pekerjaan menjadi lebih efisien dan efektif di lingkungan kerjanya. Selain itu, yang perlu ditekankan dalam kepemimpinan milenial yaitu memiliki jiwa inovasi, kreativitas, dan jiwa entrepreneurship atau disebut juga Agile. Semua Pemimpin milenial dapat dapat menjadi pemimpin yang cerdik dengan memanfaatkan peluang, juga mampu menciptakan tren-tren baru dan mempunyai pemikiran yang lebih maju sehingga membuat posisinya dapat berada di garis depan. Pola kepemimpinan lain yang perlu ditekankan adalah Unbeatable (Pantang Menyerah), yaitu seorang pemimpin milenial harus mempunyai pola pikir pantang menyerah dalam menghadapi genersi milenial yang mempunyai sifat malas. Selain itu pemimpin milenial harus mempunyai sikap positive thinking dan semangat tinggi dalam setiap masalah yang dihadapi.

Sedangkan menurut (R. A., Patterson \& Chan, 2012), karakteristik yang harus dipunyai pemimpin milenal adalah pemimpin dapat menjadi teladan yang baik bagi bawahannya, mempunyai rasa tanggung jawab terhadap pekerjaannya, dalam bekerja berani menghadapi resiko, mempunyai sense of belonging atau rasa kepemilikan dari para bawahan dan sense of participation atau rasa partisipasi dan dapat menciptakan kerjasama yang baik dengan bawahannya. 
Menurut George R Terry dalam (Rivai \& Amar, 2013) mengemukakan tentang sifat yang harus dimiliki seorang pemimpin. Sifat pertama adalah yang pertama Energi karena untuk menjadi pemimpin yang baik dibutuhkan energi yang baik pula, yang berasal jasmani maupun rohani yang sehat sehingga mampu bekerja keras sepanjang waktu. Seorang pemimpin harus mempunyai sifat memiliki stabilitas emosi yang dapat membebaskan dari prasangka terhadap bawahannya, sebaliknya pemimpin juga harus dapat bersifat tegas dalam tindakannya. Selanjutnya seorang pemimpin harus mempunyai sifat Motivasi yaitu mempunyai keinginan untuk memimpin datang dari dorongan batin pribadinya sendiri bukan paksaan dari luar dirinya sedangkan kekuatan dari luar bersifat pendorong saja. Sifat pemimpin lainnya adalah pandai berkomunikasi dalam hal mampu menyampaikan gagasan baik secara lisan maupun tulisan sehingga dapat mendorong bawahannya menjadi lebih maju, juga dapat menyampaikan atau menerima informasi bagi kemajuan organisasi. Sifat pemimpin lainnya adalah kecakapan sosial dalam memahami tentang bawahannya dan mempunyai kemampuan untuk bekerja sama dengan bawahan. Sifat terakhir yang diperlukan seorang pemimpin adalah kemampuan teknis sehingga akan lebih mudah dikoreksi bila terjadi suatu kesalahan dalam pelaksanaan tugasnya. (Martoyo, 2000).

\section{Tujuan dan Manfaat}

Tujuan utama dari kegiatan pengabdian masyarakat ini adalah menjadikan Karang taruna Warga di RW 013 Cipinang Melayu Jakarta Timur yang anggotanya merupakan generasi muda meningkatkan wawasan tentang pengetahuan di bidang kepemimpinan. Kegiatan pengabdian masyarakat ini juga bertujuan membentuk generasi muda menjadi generasi pemimpin-pemimpin milenial sehingga dapat mengetahui setiap kelebihan maupun kekurangannya agar menjadi seorang pemimpin yang lebih bijaksana dan dewasa.

Sementara itu, untuk ibu-ibu PKK Warga di RW 013 Cipinang Melayu Jakarta Timur mempunyai tujuan agar ibu-ibu sebagai orang tua di era milenial mampu untuk mendidik anaknya sedini mungkin, dalam membentuk moral dan pola pikir yang baik untuk menciptakan generasi pemimpin milenial yang mempunyai karakter sesuai dengan Pancasila. Dengan demikian, untuk kedepannya generasi muda menjadi generasi yang diharapkan dapat membawa Indonesia menjadi lebih baik.

Kegiatan pengabdian masyarakat pelatihan tentang kepemimpinan memberikan manfaat bagi peserta pengabdian masyarakat yaitu menambah ilmu dan pengetahuan di bidang kepemimpinan. Kesadaran sebagai generasi penerus bangsa yang dapat mengetahui setiap kelebihan maupun kekurangannya agar menjadi seorang pemimpin milenial yang lebih bijaksana dan dewasa. Sedangkan untuk ibuibu PKK menyadari perannya sebagai orang tua dalam mendidik anaknya sedini mungkin, dalam membentuk moral dan pola pikir yang baik untuk menciptakan generasi pemimpin milenial yang mempunyai karakter sesuai dengan Pancasila. Sedangkan manfaat kegiatan pengabdian masyarakat bagi pihak penyelenggara, yaitu para dosen Program Studi Administrasi Bisnis, adalah memperoleh 
kesempatan untuk melaksanakan salah satu kewajiban seperti tertuang dalam Tri Dharma Perguruan Tinggi yaitu Pengabdian Masyarakat kepada generasi muda serta memberdayakan perempuan, khususnya kaum ibu yang diharapkan dapat menciptakan generasi pemimpin milenial.

\section{Metode}

Metode pengabdian masyarakat adalah melaksanakan pelatihan dalam bentuk ceramah (penyajian materi) dengan menggunakan powerpoint dan printout yang dibagikan sebagai sarana pendukungnya, Role-play, diskusi. Pada sesi pertama berupa pelatihan dalam bentuk ceramah atau penyajian materi mengenai generasi pemimpin milenial menggunakan powerpoint dan printout yang dibagikan sebagai alat peranya. Pemaparan materi dilakukan tidak monoton karena diselingi interaksi dengan peserta melalui pertanyaan dan jokes yang menghibur. Untuk sesi kedua melakukan Role-play, peserta melakukan suatu peran tertentu. Peserta bermain peran adalah metode agar peserta dapat memvisualisasikan peran-peran yang ada dalam dunia kepemimpinan yang nyata ke dalam suatu pertunjukan peran saat pelatihan yang kemudian melakukan diskusi bersama dengan setiap peserta memberikan penilaian, menganalisisnya dan membuat suatu kesimpulan. Menurut Melvin L. Dengan menggunakan metode ini dapat menggairahkan diskusi dan menyemarakkan suasana serta mempraktikkan keterampilan, merasakan atau mengalami seperti apa rasanya suatu kejadian. Dalam pelatihan dan praktik permainan Role-play selalu dipandu oleh tutor Bapak Suparman yang memandu dari awal hingga akhir saat berlangsung permainan.

\section{Hasil dan Pembahasan}

Kegiatan pengabdian masyarakat yang dilakukan memiliki tema "Generasi Pemimpin Milenial". Sedangkan kegiatan pengabdian masyarakat bertempat di Aula Sekretariat RT 008 RW 013 Jl. Pangkalan Jati I Cipinang Melayu Kec. Makasar Jakarta Timur 13620 pada hari Minggu, 20 Oktober 2019. Peserta merupakan karang taruna dan ibu-ibu PKK Warga di RW 013 Cipinang Melayu Jakarta Timur sedangkan panitia penyelenggara kegiatan merupakan dosen dan mahasiswa Program Studi Administrasi Bisnis di Universitas Bina Sarana Informatika yang berjumlah enam orang dengan perincian empat dosen dan dua mahasiswa.

Kegiatan berlangsung pada hari Minggu, 3 November 2019. Kegiatan dibuka dengan sambutan oleh Bapak H. Lukman selaku Ketua RW. 013 Cipinang Melayu Kec. Makasar Jakarta Timur, dan perwakilan dosen selaku perwakilan dari Universitas Bina Sarana Informatika.

Pengabdian Masyarakat merupakan kegiatan wajib yang harus dilaksanakan dalam setiap semester oleh para staf pengajar Universitas Bina Sarana Informatika, termasuk staf pengajar Program Studi Administrasi Bisnis, Fakultas Ekonomi dan Bisnis. Kegiatan PM semester ini difokuskan pada pelatihan tentang kepemimpinan dengan peserta karang taruna dan ibu-ibu PKK Warga di RW 013 Cipinang Melayu Jakarta Timur. Pada dasarnya kegiatan Pengabdian Masyarakat ini dilaksanakan melalui beberapa tahap, antara lain :

\section{Tahap Persiapan}


Tahap ini menjadi tahap awal sebelum pelaksanaan ke tahap berikutnya yaitu tahap pelaksanaan. Agar saat pelaksanaan berjalan lancar, maka tahap persiapan ini diperlukan untuk persiapan pelaksaan pengabdian masyarakat sehingga tidak ada satu komponenpun yang terlewatkan atau terlupakan.

Tahap persiapan dilasanakan sehari sebelum tahap pelaksanaan yaitu hari Sabtu, tanggal 2 November 2019 yang terdiri atas persiapan awal atau tahap perencanaan dan persiapan akhir atau menjelang dimulainya kegiatan. Dalam tahap perencanaan ini, panitia penyelenggara kegiatan pengabdian masyarakat melakukan koordinasi pada semua pihak yang terlibat. baik dari Universitas Bina Sarana Informatika sendiri maupun dengan mitra yaitu dengan pihak RW 013 Cipinang Melayu Jakarta Timur. Koordinasi yang dibahas mengenai segala sesuatu yang perlu dipersiapkan untuk kegiatan pengabdian seperti materi dalam pelatihan, peralatan dalam role play, modul pelatihan, LCD untuk memberikan materi, snack untuk panitia dan peserta, souvenir, dan transportasi. Sedangkan bagi mitra berkoordinasi mengenai kesiapan tempat di aula sekretariat, perlengkapan pendukung, serta kesediaan peserta itu sendiri yang dipastikan terdiri dari 25 orang.

\section{Pelaksanaan}

Penyelenggaraan Pelatihan Generasi Pemimpin Milenial dipandu oleh para dosen dibantu mahasiswa Program Studi Administrasi Bisnis, Universitas BSI dan para peserta yang merupakan anggota Karang Taruna dan ibu-ibu PKK di lingkungan RW. 013 Cipinang Melayu Kec. Makasar Jakarta Timur. Acara dibuka oleh Bapak H. Lukman selaku Ketua RW. 013 Cipinang Melayu Kec. Makasar Jakarta Timur, yang menyambut gembira pelaksanaan pengabdian masyarakat ini, dan mengharapkan agar kegiatan seperti ini bisa dilaksanakan secara berkelanjutan di masa datang.

Pengabdian masyarakat dengan tema Generasi Pemimpin Milenial dilaksanakan dua sesi, yaitu sesi pertama yaitu penyampaian ceramah (penyajian materi), kemudian sesi kedua dilakukan role play dan dilanjutkan dengan mendiskusikan hasil dari permainan peran tersebut. Dalam sesi pertama yaitu ceramah atau penyampaian materi, dosen yang bertugas sebagai penyampai materi menerangkan tentang pengertian pemimpin milenial, sifat dan karakteristik pemimpin milenial. Selain itu, dijelaskan juga bagaimana membentuk mindset atau pola pikir generasi muda agar mempunyai karakteristik pola kepemimpinan milenial yaitu menjadi pemimpin yang dapat menjadi teladan yang baik bagi bawahannya, mempunyai rasa tanggung jawab terhadap pekerjaannya, bersedia menerima resiko, pemimpin yang mempunyai sense of belonging yaitu rasa kepemilikan terhadap bawahan serta sense of participation atau rasa partisipasi, dan pemimpin yang dapat menciptakan kerjasama yang baik dengan bawahannya. Hal ini merupakan beberapa karakter yang seharusnya terdapat pada seorang pemimpin generasi milenial. Generasi milenial juga harus mempunyai kemampuan dalam menggunakan teknologi untuk mengakses informasi yang lebih baik melalui media sosial. Generasi milenial juga harus mempunyai keberanian dalam berinovasi karena dapat menciptakan tantangan serta memiliki jiwa kemandirian dalam melakukan sesuatu. Semua materi dijelaskan kalimat-kalimat sederhana disertai gambar yang menarik ditunjang dengan sarana pendukung menggunakan power point diselingi pemutaran video 
dan peserta bisa mengikuti melalui modul yang dibagikan. Pemaparan materi dilakukan tidak monoton karena diselingi interaksi dengan peserta melalui pertanyaan dan jokes yang menghibur.

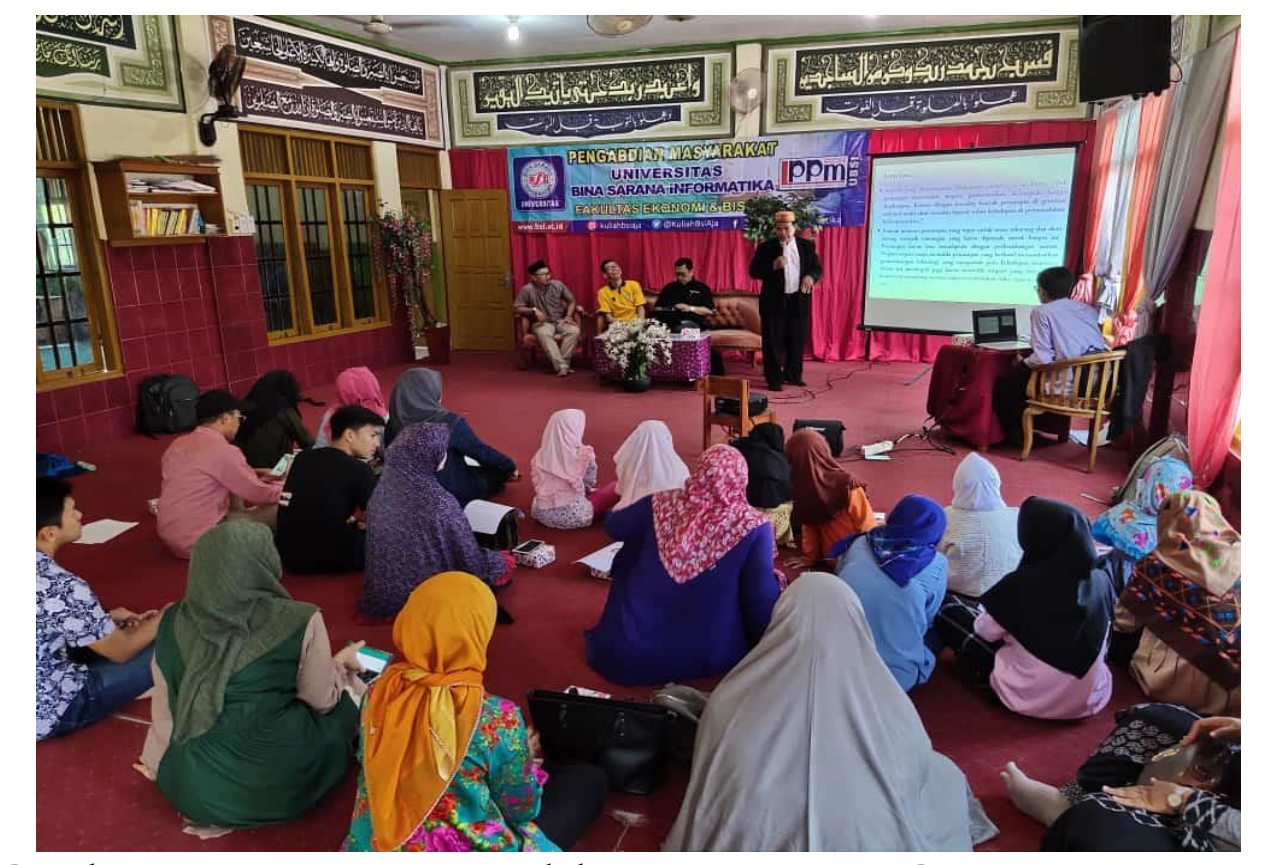

Gambar 1. Penyajian materi oleh tutor mengenai Generasi Pemimpin Milenial

Setelah selesai sesi pertama dilanjutkan sesi kedua yaitu sesi roleplay. Pada para peserta diberikan kesempatan untuk memilih peran dalam suatu plot drama, sesi ini peserta dan tutor menjelaskan berbagai karakter yang harus peserta perankan. Ada yang memerankan peran pemimpin, bawahan, partner, dan ada juga yang memerankan sebagai orang tua dari seorang generasi muda. Peserta diarahkan oleh tutor agar ada terpaku pada dialog teks karena mereka dituntut untuk berlakon dan bercakap secara spontan. Sedangkan peserta yang tidak ikut terlibat dalam permainan drama menyiapkan diri sebagai pengamat. Setelah semua siap, maka peserta mulai melakonkan drama, sesuai dengan peran masing-masing. Apabila permainan drama dirasa sudah cukup maka permainan drama dapat diberhentikan, jangan sampai terjadi peserta keasyikan bermain peran sehingga mamakan waktu yang terlampau lama. Tutor perlu menghitung waktu yang dibutuhkan dalam bermain peran. Setiap menyelesaikan memainkan suatu babak dalam drama, kemudian semua peserta mendiskusikan tentang drama yang dimainkan. Setelah drama selesai dilakukan, dilanjutkan dengan diskusi bersama semua peserta dipandu oleh tutor. Diskusi akan berhasil dengan baik apabila pemeran dan pengamat telah terlibat secara emosional dan secara intelektual. Tutor akan melontarkan suatu pertanyaan sehingga peserta akan terpancing untuk berdiskusi. 


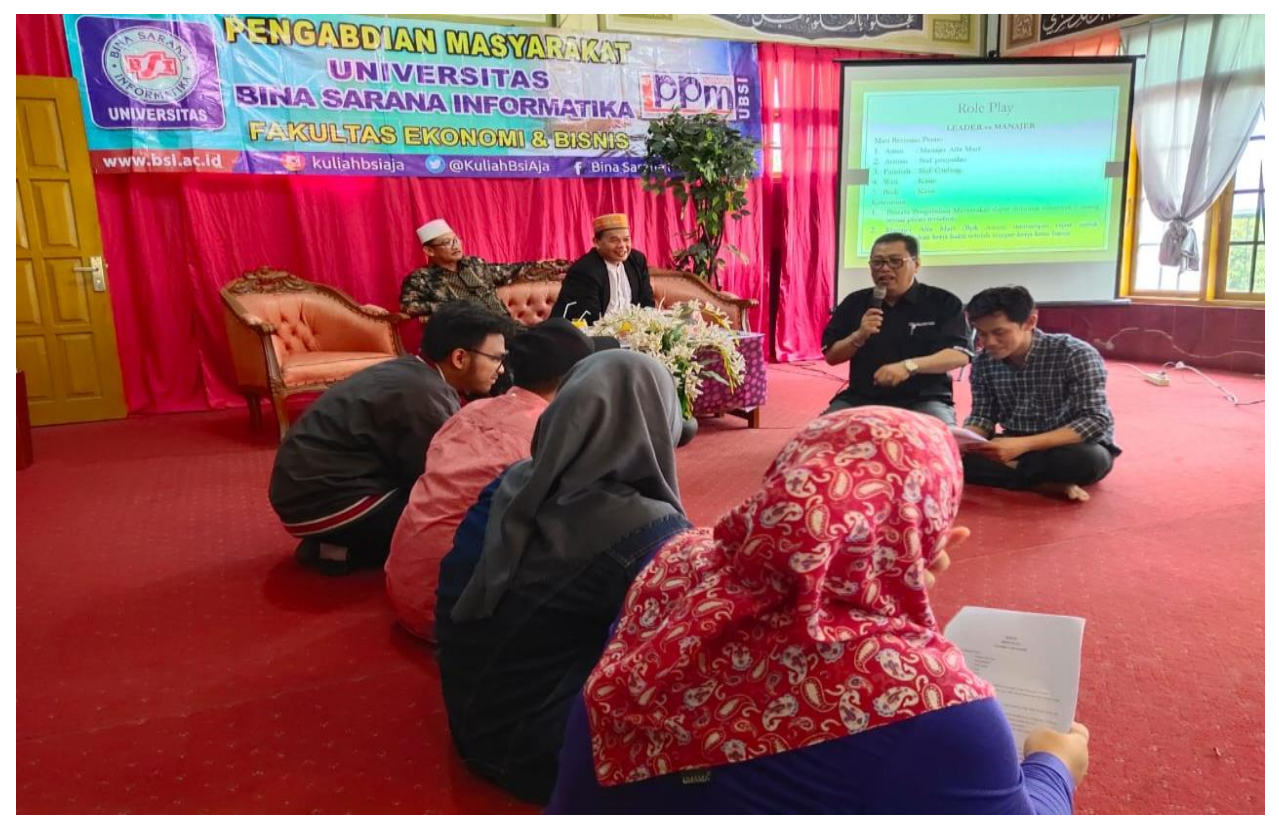

Gambar 2. Permainan Role Play yang dipandu oleh tutor

Semua pihak yang terlibat paniti maupun peserta berkolaborasi dengan sangat baik sehingga menciptakan suasana yang menyenangkan dan penuh kekeluargaan.

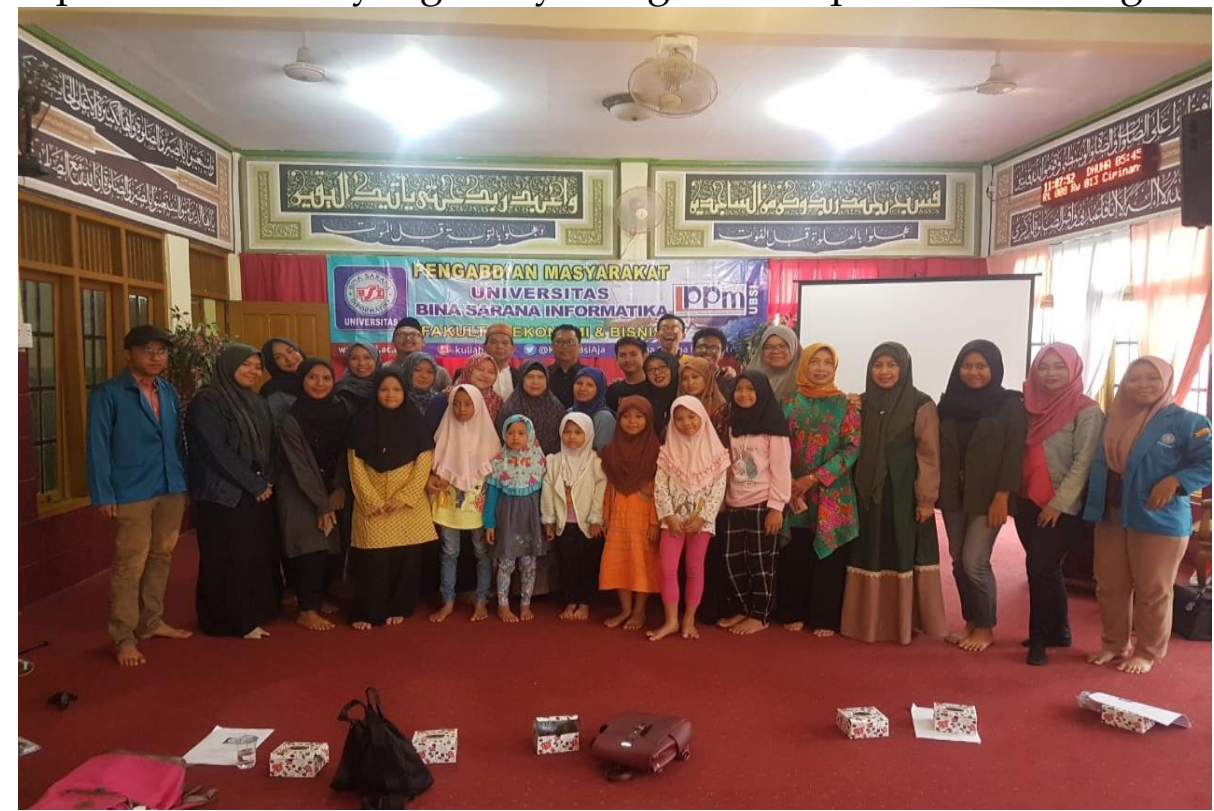

Gambar 3. Panitia dan Peserta Pengabdian Masyarakat

\section{Evaluasi}

Setelah pelaksanaan Pengabdian Masyarakat sudah selesai, selanjutnya panitia melaksanakan evaluasi yang dilakukan secara menyeluruh, dari tahap awal yaitu tahap perencanaan, saat pelaksanaan, praktik, sampai dengan diskusi. Evaluasi dilaksanakan sehari setelah pelaksanaan yaitu hari Senin tanggal 4 November 2019. Evaluasi sendiri bertujuan untuk mengetahui apakah kegiatan perencanaan yang sudah cukup lengkap, apakah pelaksanaan kegiatan sesuai dengan yang sudah direncanakan, apakah hasil yang didapatkan sudah sesuai dengan yang diharapkan, apa saja hambatan atau kendala yang dihadapi saat pelaksanaan berlangsung, dan 
hal apa saja yang dapat dikembangkan atau ditambahkan agar kegiatan yang akan datang dapat terselenggara lebih sukses dan menghasilkan banyak manfaat bagi peserta, panitia, maupun masyarakat.

Hasil evalusi secara garis besar dapat dievaluasi bahwa kegiatan pelatihan pengabdian masyarakat mengenai generasi pemimpin milenial berlangsung sukses sesuai dengan yang sudah direncanakan. Para peserta generasi muda yang direncanakan hadir 25 peserta dan yang datang 25 peserta., sehingga hanya selisih satu orang saja yang tidak hadir. Pola pikir peserta menjadi generasi pemimpin milenial sudah terbentuk dengan memahami karateristik menjadi seorang pemimpin milenial dan mempunyai pola perilaku dominan berbasis teknologi canggih, secara online, digital disertai kreatifitas yang tinggi dan peserta mempunyai kesadaran dalam mendorong terciptanya inovasi, jiwa kreativitas, dan jiwa entrepreneurship yang telah dirancang dengan baik dan nyata karena tidak hanya berisi ide atau wacana saja, tetapi juga terdapat proses yang benar-benar dapat dinikmati generasi milenial untuk dapat mengembangkan dirinya. Peserta dapat menggambarkan seorang pemimpin milenial sebagai seorang pemimpin yang cerdik dalam melihat peluang dan cepat dalam beradaptasi, juga mampu menciptakan trentren baru dan mempunyai pemikiran yang lebih maju. Peserta menyadari bahwa generasi pemimpin milenial harus mempunyai jiwa Unbeatable atau pantang menyerah menghadapi generasi milenial yang kebanyan bersikap malas dan merasa paling benar sendiri. Peserta paham bahwa seorang pemimpin milenial harus mempunyai sikap positive thinking serta mempunyai semangat yang tinggi untuk mencapai tujuannya. Sedangkan untuk ibu-ibu PKK mulai menyadari cara seharusnya mendidik anak-anaknya sedini mungkin, dalam membentuk moral dan pola pikir yang baik agar kelak menjadi seorang pemimpin milenial di masa yang akan datang yang mempunyai karakter sesuai dengan Pancasila. Hasil evaluasi kegiatan pengabdian masyarakat di RW 013 Cipinang Melayu Jakarta Timur berjalan dengan lancar seperti yang diharapkan, walaupun ada sedikit kendala yaitu saat permainan role play ada beberapa pemeran merasa kesulitan dalam memerankan perannya dengan baik, karena mereka belum mengenal dengan baik apa yang harus diperankan dan bagaimana memerankannya tetapi setelah diarahkan oleh tutor, mereka menjadi tahu cara yang tepat untuk memerankan peran dan dapat memahaminya.

\section{Simpulan dan Rekomendasi}

Pengabdian Masyarakat yang dilaksanakan di Rukun Warga 013 Cipinang Melayu telah berlangsung dan berjalan dengan lancar dan mendapatkan banyak manfaat bagi khususnya anggota karang taruna dan ibu-ibu PKK RW 013 Cipinang Melayu Jakarta Timur dan umumnya masyarakat di wilayah tersebut serta masyarakat keseluruhan. Anggota karang taruna dan ibu-ibu PKK yang mengikuti kegiatan pelatihan mempunyai antusias yang tinggi, hal ini menunjukkan menunjukan bahwa pengabdian masyarakat dengan tema generasi pemimpin milenial yang diberikan merupakan kegiatan yang bermanfaat dan dapat menjawab masalah yang dihadapi. Pengabdian masyarakat ini dilaksanakan dengan tidak membebani peserta tidak 
dipungut biaya apapun, sebaliknya peserta akan menerima Sertifikat sebagai peserta pengabdian masyarakat dari Universitas BSI. Ke depannya peserta berharap jika pengabdian masyarakat dilakukan secara berkelanjutan dengan materi yang selalu berubah disesuaikan dengan kebutuhan masyarakat. Waktu pelatihan bisa lebih lama, sehingga peserta dapat mempelajari serta memahami materi secara lebih mendalam dan tidak terburu-buru. Rekomendasi untuk perbaikan pelaksanaan pengabdian masyarakat yang akan datang adalah memperluas undangan bagi peserta tidak hanya di kalangan karang taruna dan ibu-ibu PKK tapi di semua kalangan masyarakat sehingga akan memperluas jangkauan peserta yang dituju. Peserta diharapkan tidak melupakan materi yang telah dipelajari dan selanjutnya dapat mengimplementasikan dalam kehidupan sehari-hari, sehingga menciptakan kesadaran sebagai generasi penerus bangsa yang dapat mengetahui setiap kelebihan maupun kekurangannya agar menjadi seorang pemimpin milenial yang lebih bijaksana dan dewasa. Sedangkan untuk ibu-ibu PKK menyadari perannya sebagai orang tua dalam mendidik anaknya sedini mungkin, dalam membentuk moral dan pola pikir yang baik untuk menciptakan generasi pemimpin milenial yang mempunyai karakter sesuai dengan Pancasila.

\section{Daftar Pustaka}

Bosscher, I. C. (2013). My How Things Have Changed! Strategic Organization Development and the Transformation of Human Resource Management My How Things Have Changed! In Strategic Organization Development (18th ed., pp. $1-5)$.

Hasibuan, M. S. P. (2016). Manajemen Sumber Daya Manusia (Revisi). Jakarta: PT Bumi Aksara.

Martoyo, S. (2000). Manajemen Sumberdaya Manusia. Yogyakarta: BPFE.

Peramesti, N. P. D. Y., \& Kusmana, D. (2018). Transformasi. JURNAL MANAJEMEN PEMERINTAHAN, 10(1 Maret), 73-84.

R. A., Patterson, M. B., \& Chan, Y. E. (2012). The Qualitative Report Fostering Change in Organizational Culture Using a Critical Ethnographic Approach (17th ed., pp. 1-27).

Rivai, B. V., \& Amar, B. R. (2013). Pemimpin dan Kepemimpinan dalam Organisasi. Jakarta: PT Raja Grafindo Persada.

Rohaeni, H. (2016). Model Gaya Kepemimpina dan Motivasi terhadap Kinerja Pegawai. Ecodomica, IV(1 April), 32-47. Retrieved from https://ejournal.bsi.ac.id/ejurnal/index.php/ecodemica/article/view/294/pdf 